Original Research

\title{
In Vitro Cecal Gas and Methane Production of Soybean Hulls-Containing Diets in the Presence of Salix babylonica Extract as a Fermentation Modulator in Horses
}

\author{
Mona M.Y. Elghandour ${ }^{a}$, Jessica Chavez Cardenas-Chantres ${ }^{a}$, Alejandro Esquivel-Velázquez ${ }^{a}$, \\ Alberto Barbabosa-Pliego ${ }^{\mathrm{a}}$, Moisés Cipriano ${ }^{\mathrm{b}}$, Abdelfattah Z.M. Salem ${ }^{\mathrm{a}, *}$
}

${ }^{a}$ Facultad de Medicina Veterinaria y Zootecnia, Universidad Autónoma del Estado de México, México

${ }^{\mathrm{b}}$ Unidad Académica de Medicina Veterinaria y Zootecnia, Universidad Autónoma de Guerrero, Cd. Altamirano-Iguala, Guerrero, México

\section{A R T I C L E I N F O}

\section{Article history:}

Received 7 October 2016

Received in revised form 4 December 2016

Accepted 8 December 2016

Available online 3 January 2017

\section{Keywords:}

Cecal fermentation

Corn grain

Horse nutrition

Salix babylonica extract

Soybean hulls

\begin{abstract}
A B S T R A C T
The aim of the present study was to evaluate the cecal gas production (GP) and methane $\left(\mathrm{CH}_{4}\right)$ production as well as cecal fermentation kinetics when corn grain (CG) was replaced with soybean hulls (SHs) in horse diets in the presence of different levels of Salix babylonica (SB) extract. Corn grains were replaced with $\mathrm{SH}$ at different levels $(/ \mathrm{kg}): 0 \mathrm{~g}$ (control), $75 \mathrm{~g}$ (SH75), or $150 \mathrm{~g}$ (SH150), with the inclusion of SB extract at: 0, 0.6, 1.2, and $1.8 \mathrm{~mL} / \mathrm{g}$ dry matter $(\mathrm{DM})$ of substrates. Ration type $\times$ extract dose interactions were observed for GP and $\mathrm{CH}_{4}$ production at some incubation hours. Diets containing $\mathrm{SH}$, without the inclusion of SB extract, increased the asymptotic GP $(P=.031)$ and decreased $(P<.01)$ the rate of GP and lag time of GP. The inclusion of SB increased $(P=.009)$ the rate of GP, without affecting the asymptotic GP or lag time of GP. Besides, the SH-containing rations decreased $(P<.05) \mathrm{CH}_{4}$ production, with no effect for SB extract dose. The SH75 ration increased $(P<.05)$ cecal fermentation $\mathrm{pH}$, metabolizable energy, short chain fatty acids, and gas yield at 24 hours of incubation, but quadratically decreased partitioning factor at 24 hours of incubation $(P=.023)$, whereas SB extract dose had no effect. It is concluded that SH-containing rations had higher potential fermentation efficiency and fermentation kinetics superior to that of CG. The level of $75 \mathrm{~g} \mathrm{SH} / \mathrm{kg}$ DM was the best level of inclusion to replace 30\% CG in the diets of horses. The inclusion of SB extract did not affect the cecal fermentation kinetics of horse diets containing SH at different levels.
\end{abstract}

(c) 2017 Elsevier Inc. All rights reserved.

\section{Introduction}

During agricultural production worldwide, many by-products, which are considered as nutrient-rich feed ingredients that can be used in ruminant nutrition [1-3] as a cleaner product of animal feed and environmental conservation [4-6], are produced. Recently, the increasing prices of the major energy sources in ruminant diets (i.e.,

\footnotetext{
* Corresponding author at: Abdelfattah Z.M. Salem, Universidad Autónoma del Estado de México, 50000 Toluca, Estado de México, México.

E-mail address: asalem70@yahoo.com (A.Z.M. Salem).
}

cereals) are compelling animal nutritionists to look for inexpensive alternatives to replace the expensive grains. However, some factors, such as good nutritive value and absence of food value to humans, should be considered before utilizing unconventional feedstuffs or agricultural by-products as feed ingredients for livestock.

Soybean hulls ( $\mathrm{SH}$ ) have been successfully used in nutrition of ruminants [7,8] and in horses [9] as an economic substitute for conventional feedstuffs. According to Costa et al [7], SH contained (/kg dry matter [DM]): $116 \mathrm{~g}$ crude protein (CP), $722 \mathrm{~g}$ neutral detergent fiber (NDF), and $411 \mathrm{~g}$ acid detergent fiber (ADF). Higher fiber content makes SH a low energy density and fibrous feed. Therefore, 
the inclusion of $\mathrm{SH}$ in the diet livestock may require supplementation with a rumen fermentative modulator to improve its nutritive value as an energy additive in ruminant diets [4].

Exogenous fibrolytic enzymes [10-12], like Saccharomyces cerevisiae $[13,14]$ and Salix babylonica (SB) extract $[15,16]$, have been used as feed ingredients for ruminants and horses. Little is known about the nutritive value of SB extract in equine nutrition [17]; however, some information is available on ruminant nutrition [18]. Extract of SB has some antimicrobial effects, can modulate ruminal fermentation, and affect nutrient utilization positively [19], due to its content of a number of secondary plant metabolites such as alkaloids, saponins, and phenolics [20]. Ruminal microorganisms have the ability to utilize plant extracts at low and moderate concentrations without negative effects on rumen fermentation [20,21]. Positive effects, including enhanced feed intake [21], daily gain [22], and milk production [21], were reported with the inclusion of SB in the diets of ruminant animals. Besides, the extract of SB has also been reported to have natural anthelmintic activity [22,23]. To the best of our knowledge, only ParraGarcía et al [17] reported the effect of SB extract inclusion in diets containing prickly pear cactus as a replacement for corn grain (CG) on cecal fermentation and methane $\left(\mathrm{CH}_{4}\right)$ production in horses. Therefore, the aim of the current study was to study the effect of replacing CG in horse diets with $\mathrm{SH}$ at different levels in the presence of different levels of SB extract, as a cecal fermentation modulator, on cecal in vitro gas and $\mathrm{CH}_{4}$ productions and fermentation kinetics.

\section{Materials and Methods}

\subsection{Extract, Substrates, and Treatments}

Salix babylonica leaves were collected randomly from several young and mature trees. Leaves were freshly chopped into 1-2 cm lengths and immediately extracted at $1 \mathrm{~g}$ leaf $/ 8 \mathrm{~mL}$ of water. Plant materials were individually soaked and incubated in water in the laboratory at $25^{\circ} \mathrm{C}$ to $30^{\circ} \mathrm{C}$ for 72 hours in jars. After incubation, jars were heated to $39^{\circ} \mathrm{C}$ for 1 hour and then filtered immediately and the filtrate collected and stored at $4{ }^{\circ} \mathrm{C}$ for further use.

Three total mixed rations were prepared where CG was replaced with $\mathrm{SH}$ at three levels (/kg): $0 \mathrm{~g}$ (control), $75 \mathrm{~g}$ (SH75), or $150 \mathrm{~g}$ (SH150). The extract of SB was added at four levels: $0,0.6,1.2$, and $1.8 \mathrm{~mL} / \mathrm{g}$ DM of substrates. The ingredient and chemical composition of the diets is shown in Table 1.

\subsection{In Vitro Cecal Fermentation and Biodegradation}

Cecal contents (the inoculum source) were collected from four Criollo horses (3-4 years of age and $300 \pm 15 \mathrm{~kg}$ [body weight]) from the local slaughterhouse at Toluca, Mexico State, Mexico. Horses had about 8 hours grazing and were given water twice a day without feed supplementation. The horses were grazed predominantly on pasture containing two native grasses (Festuca arundinacea and ryegrass). Equal amounts of cecal content samples were collected from the cecum of each horse and then
Table 1

Composition of the experimental diets.

\begin{tabular}{lrrr}
\hline & Ration $^{\mathrm{a}}$ & & \\
\cline { 2 - 4 } & Control & S7H5 & SH150 \\
\hline Ingredients (g/kg DM) & & & \\
Oats straw & 249 & 248 & 248 \\
Steam rolled corn & 250 & 175 & 100 \\
Soybean hulls & 0 & 75 & 150 \\
Steam rolled barley & 250 & 250 & 250 \\
Wheat bran & 120 & 110 & 120 \\
Corn gluten feed & 30 & 30 & 30 \\
Prickly pear cactus & 30 & 30 & 20 \\
Molasses & 70 & 80 & 80 \\
Vitamins/minerals & 1 & 2 & 2 \\
Chemical composition (g/kg DM) & & & \\
Organic matter & 964 & 968 & 958 \\
Crude protein & 130 & 117 & 130 \\
Neutral detergent fiber & 356 & 385 & 395 \\
Acid detergent fiber & 121 & 115 & 193 \\
Ether extract & 24 & 24 & 18 \\
Nonstructural carbohydrates & 454 & 442 & 415 \\
\hline
\end{tabular}

Abbreviation: DM, dry matter.

a SH75, soybean hulls were included at $75 \mathrm{~g} / \mathrm{kg}$ DM of total mixed ration; SH150, soybean hulls were included at $150 \mathrm{~g} / \mathrm{kg}$ DM of total mixed ration.

b Contained: vitamin A (12,000 $000 \mathrm{IU})$, vitamin $\mathrm{D}_{3}(2,500,000 \mathrm{IU})$, vitamin $\mathrm{E}(15,000 \mathrm{IU})$, vitamin $\mathrm{K}(2.0 \mathrm{~g})$, vitamin $\mathrm{B}_{1}(2.25 \mathrm{~g})$, vitamin $\mathrm{B}_{2}$ (7.5 g), vitamin $B_{6}(3.5 \mathrm{~g})$, vitamin $B_{12}(20 \mathrm{mg})$, pantothenic acid (12.5 g), folic acid (1.5 g), biotin (125 mg), niacin (45 g), Fe (50 g), Zn (50 g), Mn (110 g), Cu (12 g), I (0.30 g), Se (200 mg), and Co (0.20 g).(Adapted from Elghandour et al [8])

mixed to obtain homogenized samples which were also mixed with the Goering and Van Soest [24] buffer solution without trypticase in the ratio of $1: 4 \mathrm{vol} / \mathrm{vol}$. The incubation media was subsequently mixed and strained through four layers of cheesecloth into a flask with an $\mathrm{O}_{2}$-free headspace and used to inoculate three identical runs of incubation in $120-\mathrm{mL}$ serum bottles containing $0.5 \mathrm{~g}$ DM of substrate in the presence of different doses of SB extract.

Bottles with substrates plus three bottles without substrate and SB as blanks were used. After filling all bottles, they were flushed with carbon dioxide and immediately closed with rubber stoppers, shaken and placed in an incubator set at $39^{\circ} \mathrm{C}$. Gas production (GP) was recorded at $2,4,6,8,10,12,14,24,36,48,54,60$, and 72 hours using the Pressure Transducer Technique (Extech instruments, Waltham) of Theodorou et al [25]. Production of $\mathrm{CH}_{4}$ was recorded using Gas-Pro detector (Gas Analyzer CROWCON Model Tetra3, Abingdon, UK) at 2, 6, 10, 14, 24, 36, 48, 54, 60 , and 72 hours of incubation.

At the end of incubation (i.e., after 72 hours), bottles were uncapped and the $\mathrm{pH}$ was measured using a digital pH meter (Conductronic pH15, Puebla, Mexico), and the residual of each bottle was filtered under vacuum through glass crucibles with a sintered filter and the fermentation residues dried at $65^{\circ} \mathrm{C}$ for 72 hours to estimate DM disappearance (DMD).

\subsection{Chemical Analyses and Calculations}

Samples of the rations were analyzed for DM (\#934.01), ash (\#942.05), nitrogen (\#954.01), and ether extract (\#920.39) according to Association of Official Analytical Chemists (AOAC) [26], whereas NDF, ADF, and lignin (\#973.18) [26] analyses were carried out using an 
ANKOM $^{200}$ Fiber Analyzer Unit (ANKOM Technology Corp, Macedon, NY) with the use of an alpha amylase and sodium sulfite.

For estimation of GP kinetic, recorded gas volumes (mL/ g DM) were fitted using the NLIN procedure of SAS [27] according to France et al [28] model:

$y=b \times\left[1-e^{-c(t-L a g)}\right]$

where $y$ is the volume of GP at time $t(\mathrm{~h}) ; b$ is the asymptotic GP ( $\mathrm{mL} / \mathrm{g} \mathrm{DM}) ; c$ is the fractional rate of fermentation $(1 / \mathrm{h})$, and $\operatorname{Lag}(\mathrm{h})$ is the discrete lag time prior to any gas release.

Metabolizable energy (ME, MJ/kg DM) was estimated according to Menke et al [29] as:

$$
\begin{aligned}
M E= & 2.20+0.136 \mathrm{GP}(\mathrm{mL} / 0.5 \mathrm{~g} D M) \\
& +0.057 \mathrm{CP}(\mathrm{g} / \mathrm{kg} \mathrm{DM})
\end{aligned}
$$

where: GP is net GP in mL from $200 \mathrm{mg}$ of dry sample after 24 hours of incubation.

The partitioning factor at 24 hours of incubation $\left(\mathrm{PF}_{24}\right.$; a measure of fermentation efficiency) was calculated as the ratio of DM degradability in vitro $(\mathrm{mg})$ to the volume $(\mathrm{mL})$ of GP at 24 hours (i.e., DMD/total GP [GP 24$]$ ) according to Blümmel et al [30]. Gas yield $\left(\mathrm{GY}_{24}\right)$ was calculated as the volume of gas (mL gas/g DM) produced after 24 hours of incubation divided by the amount of DMD (g) as:

$G Y_{24}=m L$ gas $/ g D M / g D M D$

A

Gas production at $24 \mathrm{~h}$

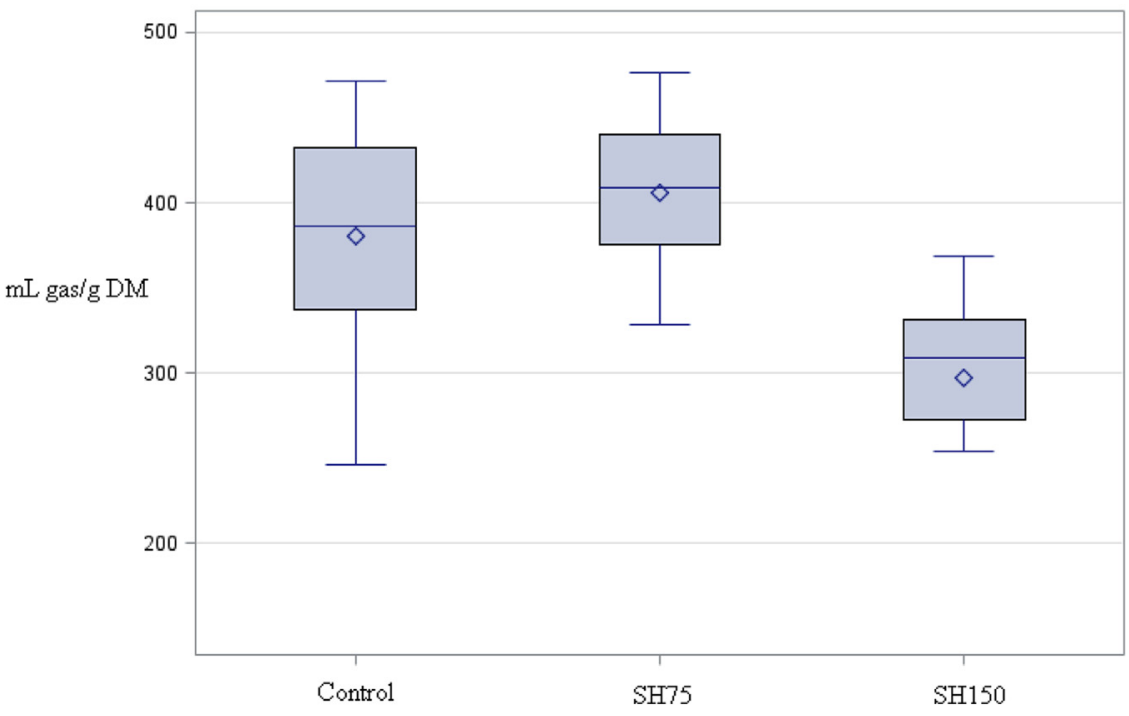

B

Gas production at $48 \mathrm{~h}$

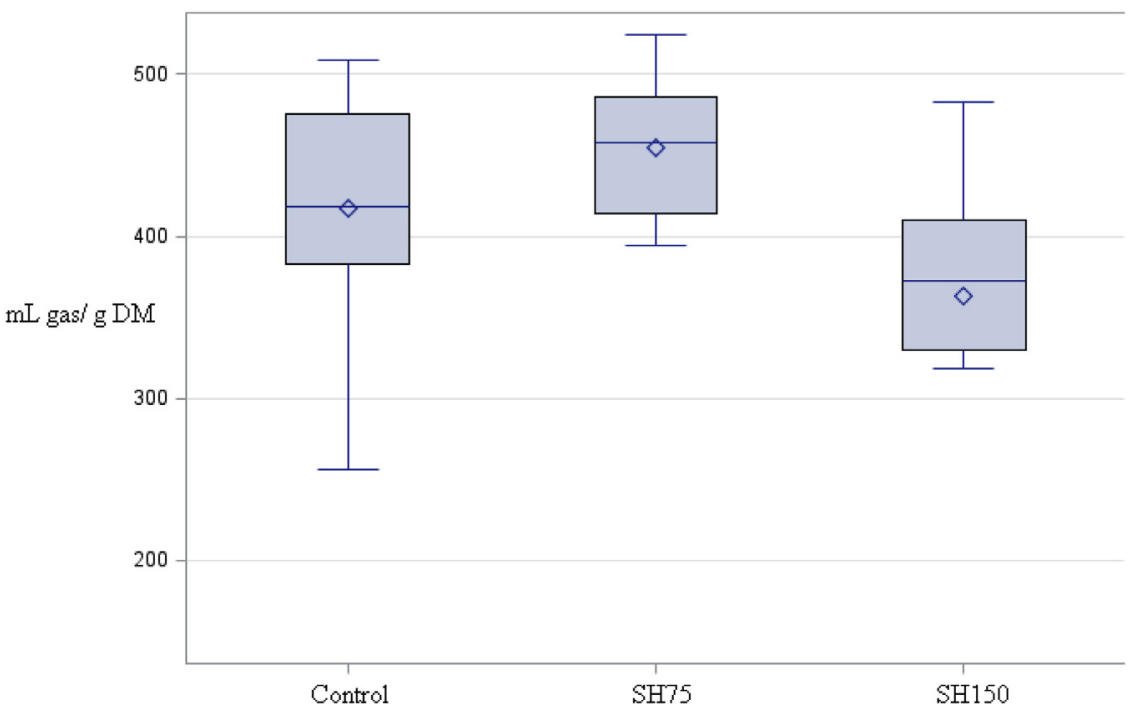

Fig. 1. Mean in vitro cecal gas production (mL/g DM) of three levels of soybean hulls (SHs) at 24 (A) and 48 (B) hours of incubation. DM, dry matter. 
Short chain fatty acid (SCFA) concentrations were calculated according to Getachew et al [31] as:

SCFA $(\mathrm{mmol} / 200 \mathrm{mg} \mathrm{DM})=0.0222 G P-0.00425$

where GP is the 24 hours net GP (mL/200 mg DM).

\subsection{Statistical Analyses}

Data from each of the three runs within the same sample of each of the three individual samples of rations were averaged prior to statistical analysis, and mean values of each individual sample were used as the experimental unit. Results of in vitro GP and cecal fermentation parameters were analyzed as a factorial experiment using the PROC GLM option of SAS [27] as:

$Y_{i j k}=\mu+R_{i}+D_{i}+(R \times D)_{i j}+E_{i j k}$

where $Y_{i j k}=$ is every observation of the ith $\mathrm{SH}$ level $\left(\mathrm{R}_{\mathrm{i}}\right)$ with jth SB extract dose $\left(D_{j}\right)$; $\mu$ is the general mean; $(R \times D)_{i j}$ is the interaction between ration type and SB extract dose;

A

Gas production at $24 \mathrm{~h}$

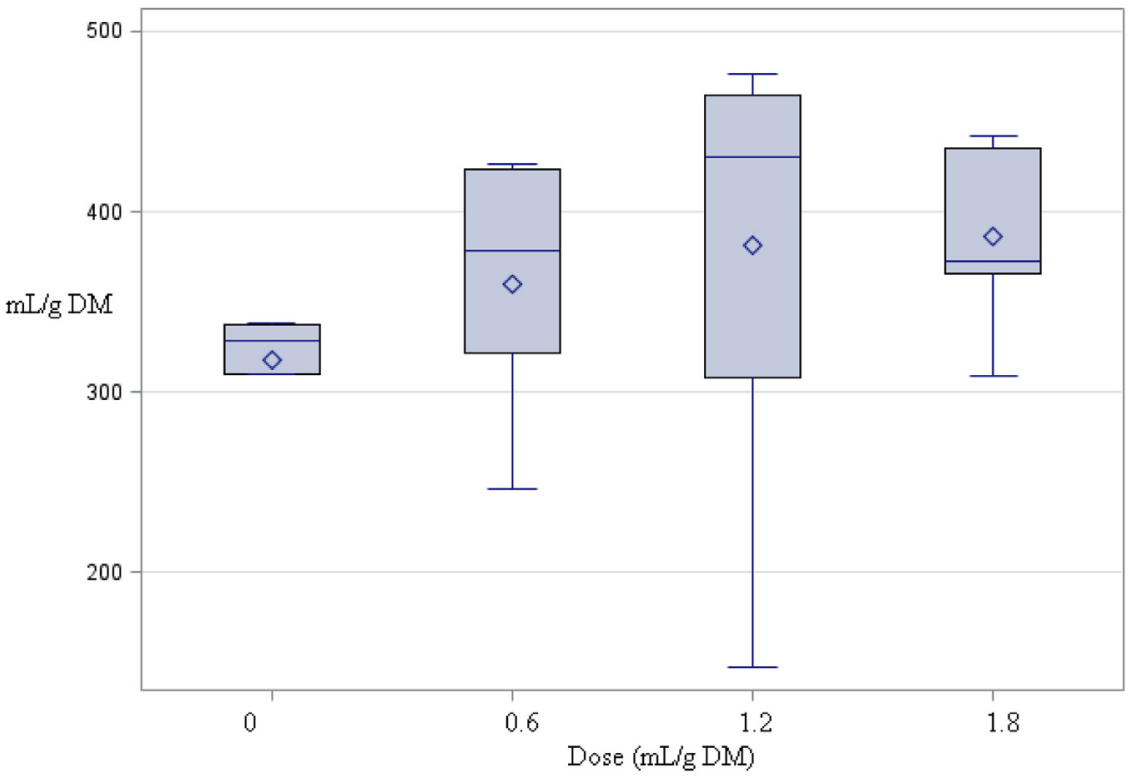

B

Gas production at $48 \mathrm{~h}$

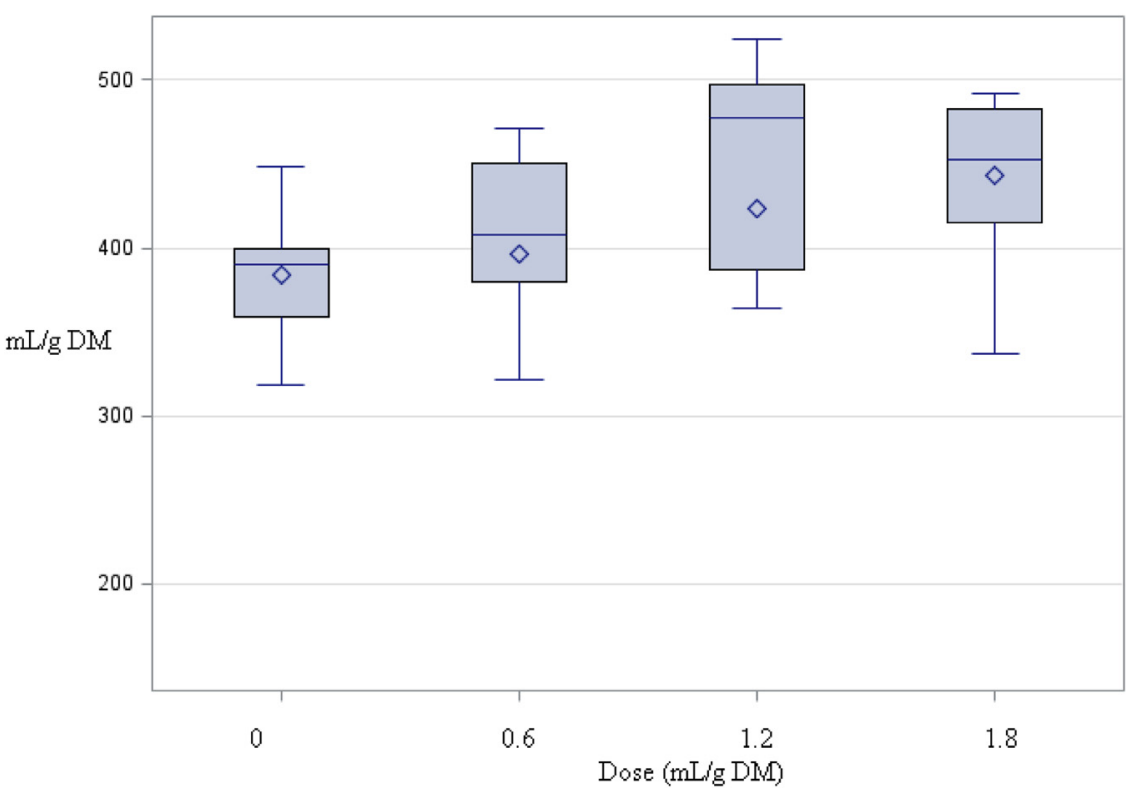

Fig. 2. Mean in vitro cecal gas production (mL/g DM) of four levels of Salix babylonica doses at 24 (A) and 48 (B) hours of incubation. DM, dry matter. 
$E_{\mathrm{ijk}}$ is the experimental error. Linear and quadratic polynomial contrasts were used to examine responses of different SH levels (rations) to increasing addition levels of $\mathrm{SB}$ extract. Statistical significance was declared at $\mathrm{P}<.05$.

\section{Results}

\subsection{Gas Production Kinetics}

Figs. 1 and 2 show the mean in vitro cecal GP (mL/g DM) of three levels of SH and four levels of SB doses, respectively at 24 hours and 48 hours of incubation. Ration type $\times$ extract dose interactions were observed for GP from 6 to 14 hours of incubation (Table 2). Replacing CG with $\mathrm{SH}$, without the inclusion of SB extract, increased the asymptotic GP (quadratic effect, $P=.031$ ) and decreased both of the rate of GP (linear effect, $P=.007$ ) and lag time of GP (linear effect, $P$ $=.003$; quadratic effect, $P<.001)$. Gas production, at all incubation hours, differed among the different rations. The inclusion of SB extract did not affect $(P>.05)$ the asymptotic GP or lag time of GP from all rations; however, it increased (quadratic effect, $P=.009$ ) the rate of GP compared with those with no SB extract inclusion. During the incubation hours from 2 to 4 hours of incubation, inclusion of SB extract linearly increased $(P<.05)$ GP from all rations compared with the rations without SB extract.

\subsection{Methane Production}

Figs. 3 and 4 show the mean in vitro cecal $\mathrm{CH}_{4}(\mathrm{~mL} / \mathrm{g}$ $\mathrm{DM}$ ) of three levels of $\mathrm{SH}$ and four levels of SB doses, respectively at 24 hours and 48 hours of incubation. Interactions between ration type and SB extract dose were observed $(P<.05)$ at 24,36 , and 48 hours of incubation (Table 3). No $\mathrm{CH}_{4}$ was produced during the incubation hours from 2 to 14 hours. With no SB extract inclusion, replacing $\mathrm{CG}$ with $\mathrm{SH}$ decreased (linear and quadratic effects, $P<.05) \mathrm{CH}_{4}$ production at incubation hours from 48 to 72 hours of incubation. Inclusion of SB extract did not affect $\mathrm{CH}_{4}$ production during all incubation hours, with exception of $\mathrm{CH}_{4}$ production at 36 hours of incubation (linear and quadratic effect, $P<.05$ ).

\subsection{Cecal Fermentation Kinetics}

Although there were no interactions $(P>.05)$ between ration type and $\mathrm{SB}$ extract dose for ME, DMD, SCFA, $\mathrm{PF}_{24}$, and $\mathrm{GY}_{24}$, interaction was observed for cecal fermentation $\mathrm{pH}(P=.002)$ (Table 4$)$. Ration effects on fermentation kinetic parameters were significant with $\mathrm{SH} 75$ ration having increased cecal fermentation $\mathrm{pH}$ (linear effect, $P=.004$ ), ME (quadratic effect, $P=.003$ ), SCFA (quadratic effect, $P=$ .003 ), and $\mathrm{GY}_{24}$ (quadratic effect, $P=.016$ ) and quadratically decreased $\mathrm{PF}_{24}(P=.023)$. Inclusion of SB extract did not affect $(P>.05)$ the fermentation kinetic parameters.

\section{Discussion}

\subsection{Gas Production}

The occurrence of ration type $\times$ extract dose interaction effect on GP from 2 to 14 hours of incubation hours reveals that the effect of SB extract dose on GP at these hours depended on ration type (i.e., SH level in the diet). On the other hand, the absence of interaction between these two factors on GP for the rest of the incubation hours (i.e., from

Table 2

In vitro cecal gas kinetics of three levels of soybean hulls (SHs) at different levels (mg/g DM) of Salix babylonica (SB) extract inclusion (mL/g DM).

\begin{tabular}{|c|c|c|c|c|c|c|c|c|c|c|c|c|c|c|c|c|c|c|c|}
\hline \multirow[t]{2}{*}{ Ration $^{\mathrm{a}}$} & \multirow[t]{2}{*}{ SB Extract } & & \multicolumn{4}{|c|}{$\begin{array}{l}\text { Gas Production } \\
\text { Parameters }^{b}\end{array}$} & \multicolumn{13}{|c|}{ Gas Production (mL/g DM) at } \\
\hline & & \multicolumn{2}{|r|}{$b$} & \multicolumn{2}{|l|}{$c$} & Lag & $2 \mathrm{hr}$ & $4 \mathrm{hr}$ & \multirow{2}{*}{$\frac{6 \mathrm{hr}}{149}$} & \multirow{2}{*}{$\frac{8 \mathrm{hr}}{185}$} & \multirow{2}{*}{$\frac{10 \mathrm{hr}}{214}$} & $12 \mathrm{hr}$ & $14 \mathrm{hr}$ & $24 \mathrm{hr}$ & $36 \mathrm{hr}$ & $48 \mathrm{hr}$ & $54 \mathrm{hr}$ & $60 \mathrm{hr}$ & $72 \mathrm{hr}$ \\
\hline \multirow[t]{4}{*}{ Control } & 0 & & 381 & 0.0 & 83 & 8.85 & 58 & 107 & & & & 240 & 261 & 329 & 362 & 374 & 377 & 379 & 380 \\
\hline & 0.6 & & 369 & 0.1 & 25 & 7.45 & 80 & 143 & 192 & 231 & 261 & 284 & 303 & 350 & 365 & 368 & 369 & 369 & 369 \\
\hline & 1.2 & & 473 & & 04 & 7.32 & 88 & 160 & 218 & 266 & 304 & 335 & 361 & 432 & 461 & 469 & 471 & 471 & 472 \\
\hline & 1.8 & & 463 & 0.0 & 93 & 7.02 & 79 & 144 & 198 & 243 & 280 & 311 & 337 & 412 & 446 & 457 & 459 & 461 & 462 \\
\hline \multirow[t]{4}{*}{ SH75 } & 0 & & 429 & & 70 & 6.57 & 56 & 105 & 147 & 184 & 216 & 244 & 268 & 349 & 394 & 414 & 419 & 423 & 426 \\
\hline & 0.6 & & 454 & & 04 & 5.60 & 85 & 154 & 210 & 255 & 292 & 322 & 346 & 415 & 442 & 450 & 452 & 453 & 453 \\
\hline & 1.2 & & 505 & & 02 & 5.99 & 93 & 168 & 230 & 280 & 321 & 355 & 382 & 460 & 491 & 500 & 502 & 503 & 504 \\
\hline & 1.8 & & 462 & & 86 & 5.34 & 73 & 133 & 184 & 227 & 263 & 293 & 319 & 398 & 437 & 452 & 456 & 458 & 461 \\
\hline \multirow[t]{4}{*}{ SH150 } & 0 & & 406 & & 48 & 4.01 & 37 & 70 & 101 & 128 & 154 & 176 & 197 & 275 & 331 & 363 & 374 & 381 & 392 \\
\hline & 0.6 & & 381 & & 74 & 5.17 & 52 & 97 & 136 & 170 & 199 & 224 & 245 & 316 & 354 & 370 & 374 & 376 & 379 \\
\hline & 1.2 & & 315 & & 97 & 3.99 & 45 & 82 & 113 & 139 & 161 & 180 & 197 & 252 & 285 & 300 & 305 & 308 & 312 \\
\hline & 1.8 & & 446 & & 72 & 4.72 & 56 & 104 & 146 & 183 & 214 & 242 & 266 & 347 & 396 & 420 & 427 & 432 & 438 \\
\hline \multicolumn{3}{|c|}{ Pooled SEM } & 39.1 & & 126 & 0.774 & 5.0 & 8.8 & 11.9 & 14.4 & 16.6 & 18.5 & 20.2 & 26.8 & 32.0 & 35.1 & 36.1 & 36.9 & 37.8 \\
\hline \multicolumn{20}{|c|}{$P$ value } \\
\hline \multicolumn{20}{|c|}{ Ration effect } \\
\hline \multicolumn{2}{|c|}{ Linear } & .15 & .2 & & .003 & $.95^{\circ}$ & & .817 & .690 & .578 & .485 & .409 & .350 & .20 & .156 & .148 & .146 & .146 & .147 \\
\hline \multirow{2}{*}{\multicolumn{2}{|c|}{$\begin{array}{l}\text { Quadratic } \\
\text { Dose effect }\end{array}$}} & .03 & .00 & & $<.001$ & $<.00$ & & $<.001$ & $<.001$ & $<.001$ & $<.001$ & $<.001$ & $<.001$ & $<.00$ & .003 & .003 & .005 & .008 & .015 \\
\hline & & & & & & & & & & & & & & & & & & & \\
\hline Line & & .12 & .13 & & .229 & .00 & & .001 & .001 & .002 & .003 & .004 & .006 & .00 & .022 & .049 & .063 & .075 & .093 \\
\hline Qua & dratic & .98 & .00 & & .562 & .002 & & .004 & .007 & .002 & .003 & .006 & .012 & .13 & .445 & .695 & .779 & .841 & .919 \\
\hline Ration & $\times$ dose & .19 & .76 & & .618 & .070 & & .054 & .045 & .040 & .037 & .037 & .038 & .06 & .107 & .147 & .161 & .171 & .183 \\
\hline
\end{tabular}

Abbreviations: DM, dry matter; SEM, standard error of the mean.

a SH75, soybean hulls were included at $75 \mathrm{~g} / \mathrm{kg} \mathrm{DM}$ of total mixed ration; SH150, soybean hulls were included at $150 \mathrm{~g} / \mathrm{kg}$ DM of total mixed ration.

b $b$ is the asymptotic gas production ( $\mathrm{mL} / \mathrm{g} \mathrm{DM}) ; c$ is the rate of gas production $(1 / \mathrm{h})$; Lag is the initial delay before gas production begins (h). 


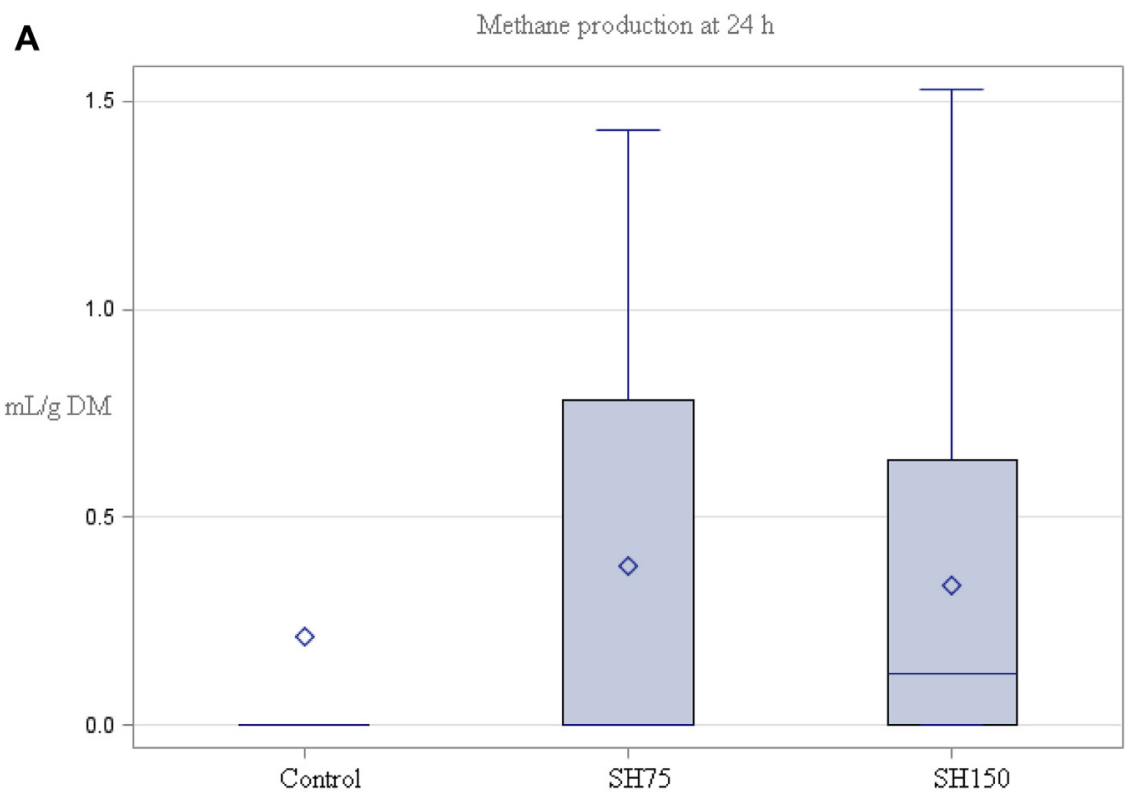

B Methane production at $48 \mathrm{~h}$

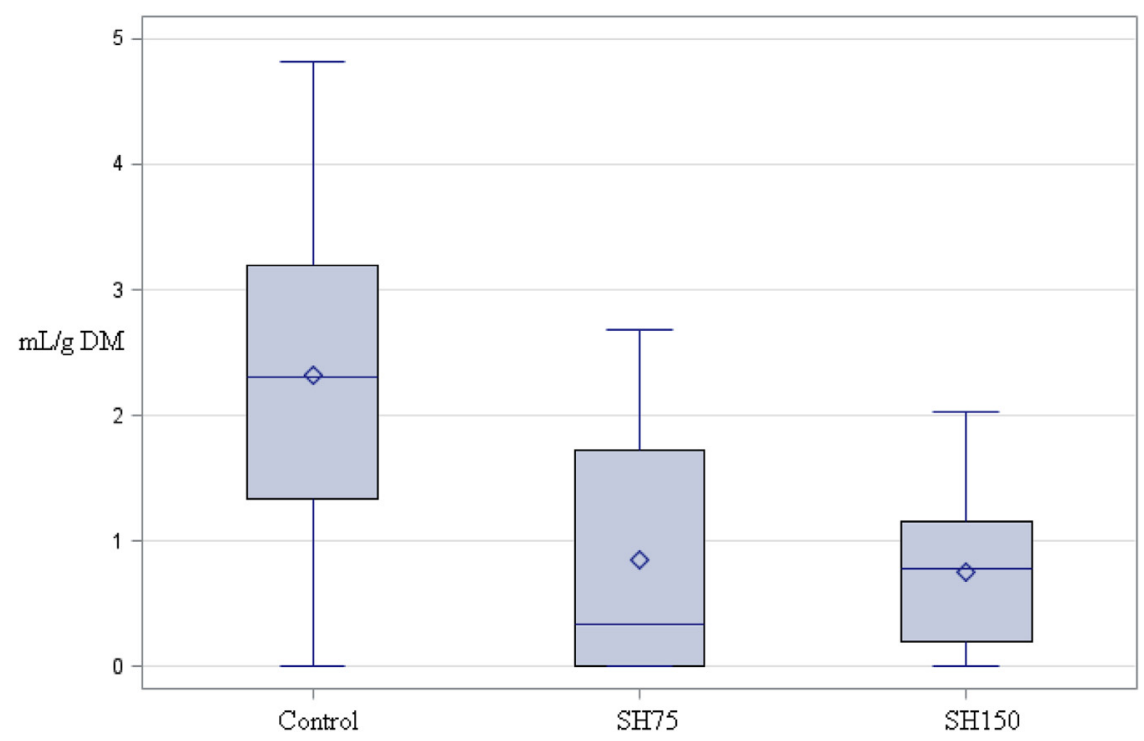

Fig. 3. Mean in vitro cecal methane production ( $\mathrm{mL} / \mathrm{g} \mathrm{DM})$ of three levels of soybean hulls (SH) at 24 (A) hours and 48 (B) hours of incubation. DM, dry matter.

24 to 72 hours) indicates that beyond 14 hours of incubation, both ration type and SB extract dose were independent of each and thus did not have synergistic effect on GP. Similarly, lack of ration type $\times$ SB extract dose interaction effect on GP parameters is an indication of independency of the two factors. Therefore, it would be better to discuss the effect of ration type and SB extract dose separately. The rations SH75 and SH150 had higher GP with lower rate and lag time of GP compared with the control ration. Increased GP is a good indicator of improved nutrient digestibility, fermentability, and rumen microbial protein production $[32,33]$. Higher GP has also been reported to indicate higher nutrient availability for ruminal microorganisms [34]. In corroboration of previous studies, Velázquez et al [9] observed unaffected fecal horse GP parameters when CG was replaced with $\mathrm{SH}$ at the same levels used in the present experiment. Similarly, Elghandour et al [8], using rumen liquor as a bacterial inoculum, obtained unaffected GP parameters when CG replaced SH.

The decreased rate and lag time of GP with replacing CG with $\mathrm{SH}$ is an indicator of increased fermentation of the insoluble but degradable fraction in the incubated substrates [8]. These results suggest a steady increase in availability of the carbohydrate fractions to the microbial population for growth and other activities and are in agreement with previous studies [33,34]. According to 

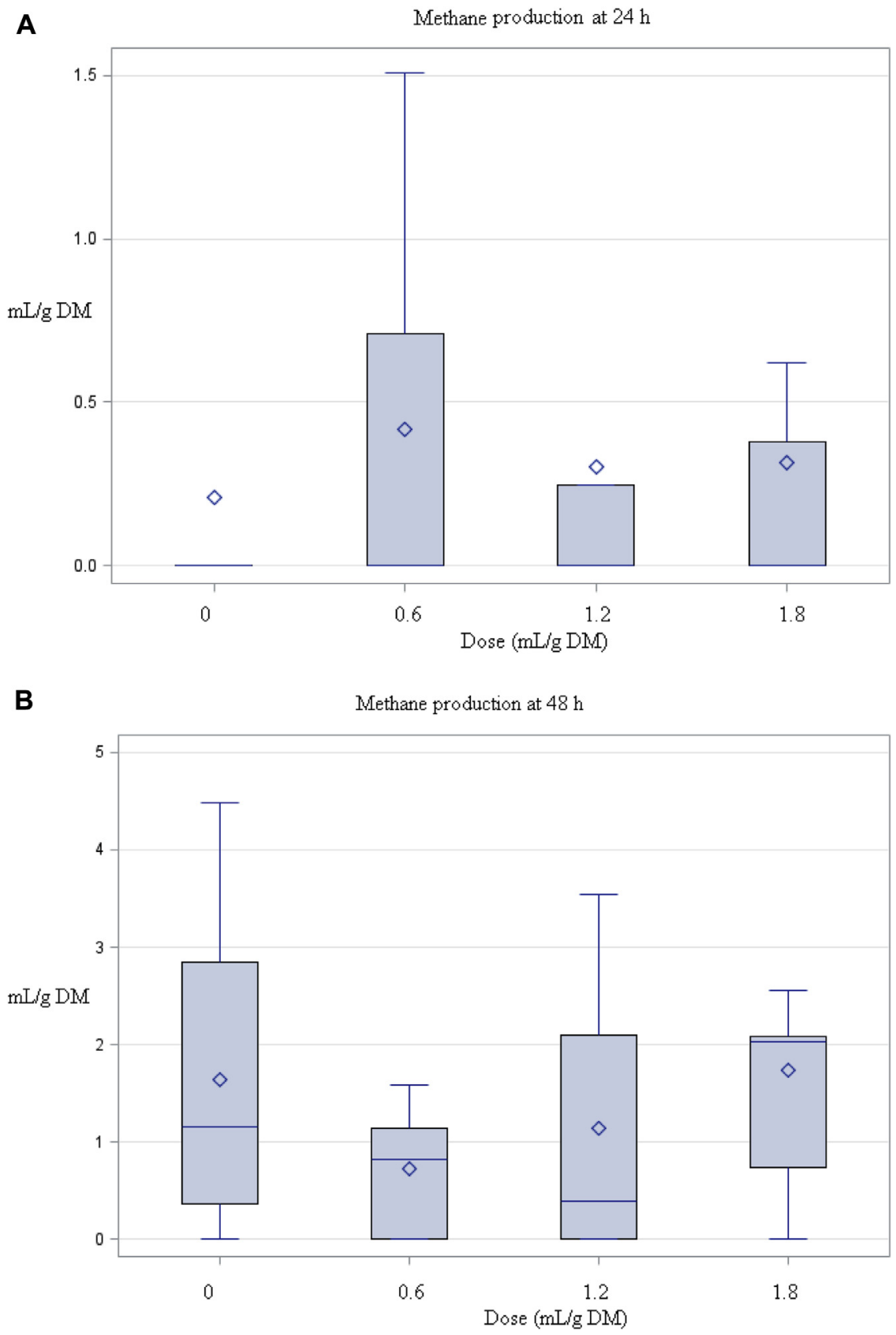

Fig. 4. Mean in vitro cecal methane production (mL/g DM) of four levels of Salix babylonica doses at 24 (A) and 48 (B) hours of incubation. DM, dry matter.

Blümmel and Ørskov [35], the asymptotic GP could be used to predict feed intake because $88 \%$ of variance in intake is accounted for by GP. This implies that the SH75 and SH150 rations had the tendency to induce feed intake and growth rate in ruminants [35] and may be in horses, since fractional rate of GP was correlated with feed intake [36]. This is because performance is largely a function of feed intake, which is a better indicator of nutritive value of feed than apparent digestibility [37]. The decreased discrete lag time prior to GP with the SH75 and SH150 rations suggests faster microbial adaptation to the ration, in agreement with previous reports $[33,34]$.
Without affecting the asymptotic GP or the rate of GP, increased lag time of GP was observed with the inclusion of SB extract. This may be due to the negative effects of its secondary metabolites on the cecal microorganisms' activities; however, an ability of rumen microorganisms to degrade secondary metabolites in phytogenic extract and utilize them as an energy source was reported [38]. Negative effects of SB extract on ruminal fermentation and microorganisms have been attributed to deleterious impact of the secondary metabolites in the extract [18-21]. Parra-García et al [17], using horse cecal contents as an inoculum source, observed an unaffected asymptotic GP or rate of GP, and a 
Table 3

In vitro methane $\left(\mathrm{CH}_{4}\right)$ productions of three levels of soybean hulls ( $\left.\mathrm{SHs}\right)$ at different levels (mg/g DM) of Salix babylonica (SB) extract inclusion ( $\mathrm{mL} / \mathrm{g}$ DM).

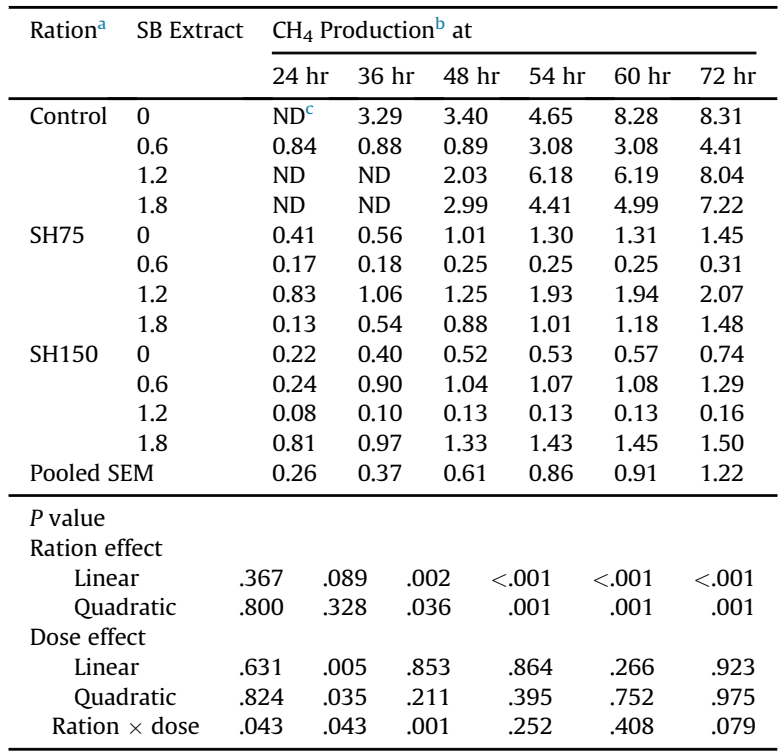

Abbreviations: DM, dry matter; SEM, standard error of the mean.

a SH75, soybean hulls were included at $75 \mathrm{~g} / \mathrm{kg}$ DM of total mixed ration; SH150, soybean hulls were included at $150 \mathrm{~g} / \mathrm{kg}$ DM of total mixed ration.

b $\mathrm{No} \mathrm{CH}_{4}$ was produced at 2, 6, 10, and 14 hours of incubation.

c ND means not detected (i.e., $0 \mathrm{~mL} \mathrm{CH}_{4} / \mathrm{g} \mathrm{DM}$ ).

decreased lag time of GP with the inclusion of SB extract in rations where CG was replaced with $\mathrm{SHs}$. Variations in the results of effect of additives on lag time of GP have been adduced to differences in the incubated substrates [8].

\subsection{Methane Production}

The occurrence of ration type $\times$ SB extract dose interaction on $\mathrm{CH}_{4}$ production reveals that $\mathrm{CH}_{4}$ production was SB extract dose and ration dependent. Both SH75 and $\mathrm{SH} 150$ rations decreased $\mathrm{CH}_{4}$ production. Methane production from ruminants depends mainly on the degradability and chemical composition of diets [5,8,39]. Livestock sector is one of the sources responsible for about $18 \%$ of greenhouse gas emission [40], as a result of ruminal fermentation of fed diets in the rumen causing a loss of digested energy [41]. Using the same rations used in the present experiment, Elghandour et al [8] observed that replacing $\mathrm{CG}$ with $\mathrm{SHs}$ did not affect $\mathrm{CH}_{4}$ production. Differences in response between the present experiment and that of Elghandour et al [8] may be due to different inoculum source (rumen contents vs. cecal contents).

The inclusion of SB extract did not affect $\mathrm{CH}_{4}$ production. Parra-García et al [17] obtained unaffected $\mathrm{CH}_{4}$ production with the inclusion of SB extract to rations where CG was replaced with SHs.

\subsection{Fermentation Kinetics}

The SH75 ration increased cecal fermentation $\mathrm{pH}$, revealing better fermentation conditions for cecal
Table 4

Degradation and in vitro cecal fermentation profile ${ }^{a}$ of three levels of soybean hulls (SHs) at different levels (mg/g DM) of Salix babylonica (SB) extract inclusion ( $\mathrm{mL} / \mathrm{g} \mathrm{DM})$.

\begin{tabular}{lllllrll}
\hline Ration $^{\mathrm{b}}$ & $\mathrm{SB}$ & $\mathrm{pH}$ & $\mathrm{ME}$ & $\mathrm{DMD}$ & $\mathrm{SCFA}$ & $\mathrm{PF}_{24}$ & $\mathrm{GY}_{24}$ \\
\hline Control & 0 & 5.43 & 13.06 & 861 & 8.28 & 4.81 & 208 \\
& 0.6 & 5.10 & 12.91 & 930 & 8.16 & 4.86 & 206 \\
& 1.2 & 6.55 & 15.64 & 885 & 10.39 & 4.66 & 215 \\
& 1.8 & 6.57 & 15.32 & 879 & 10.12 & 4.67 & 214 \\
SH75 & 0 & 6.64 & 14.13 & 827 & 9.17 & 4.74 & 211 \\
& 0.6 & 6.63 & 15.11 & 812 & 9.97 & 4.69 & 213 \\
& 1.2 & 6.57 & 16.48 & 858 & 11.09 & 4.62 & 216 \\
& 1.8 & 5.88 & 15.16 & 860 & 10.01 & 4.68 & 214 \\
SH150 & 0 & 5.86 & 12.82 & 796 & 8.05 & 4.84 & 207 \\
& 0.6 & 6.27 & 13.00 & 811 & 8.19 & 4.83 & 207 \\
& 1.2 & 5.58 & 11.11 & 828 & 6.65 & 5.17 & 195 \\
& 1.8 & 6.26 & 14.37 & 838 & 9.31 & 4.74 & 211 \\
Pooled SEM & 0.233 & 0.955 & 26.7 & 0.779 & 0.120 & 4.4 \\
\hline
\end{tabular}

$P$ value

Ration effect

$\begin{array}{llllllll}\text { Linear } & .004 & .157 & .015 & .148 & .419 & .342\end{array}$

$\begin{array}{llllllll}\text { Quadratic } & .226 & .003 & .010 & .003 & .023 & .016\end{array}$

Dose effect

$\begin{array}{llllllll}\text { Linear } & .186 & .050 & .164 & .051 & .340 & .257\end{array}$

$\begin{array}{lllllll}\text { Quadratic } & .439 & .695 & .486 & .693 & .404 & .525\end{array}$

$\begin{array}{lllllll}\text { Ration } \times \text { dose } & .002 & .148 & .576 & .147 & .265 & .229\end{array}$

Abbreviations: DM, dry matter; SEM, standard error of the mean.

a DMD is the in vitro dry matter digestibility (mg/g DM); $\mathrm{GY}_{24}$ is the gas yield at 24 hours ( $\mathrm{mL}$ gas/g DMD); ME is the metabolizable energy ( $\mathrm{MJ} / \mathrm{kg}$ $\mathrm{DM}$ ); $\mathrm{PF}_{24}$ is the partitioning factor at 24 hours of incubation ( $\mathrm{mg} \mathrm{DMD} / \mathrm{mL}$ gas); $\mathrm{pH}$ is the fermentation $\mathrm{pH}$; SCFA is the short-chain fatty acids ( $\mathrm{mmol}$ / g DM).

b SH75, soybean hulls were included at $75 \mathrm{~g} / \mathrm{kg}$ DM of total mixed ration; SH150, soybean hulls were included at $150 \mathrm{~g} / \mathrm{kg}$ DM of total mixed ration.

microbial activities for fiber degradation [42]. Also, the ration increased ME, SCFA, and $\mathrm{GY}_{24}$. Dhanoa et al [43] reported that feed degradation and fermentation rate are directly proportional to GP. Improved fermentation kinetics is the main reason for improved GP. Increased SCFA production and ME are associated with high activities of microbes in the rumen. Higher SCFA is important in terms of enhanced lactose production, milk volume, and overall energy balance in ruminants $[44,45]$. Besides, the improved fermentation parameters when CG was replaced with $\mathrm{SH}$ could be due to additional availability of the fermentable carbohydrates which possibly promoted microbial growth [46] and also improved the incubation environment. These results reveal more fermentable carbohydrates availability, enhanced degradability, and improved microbial protein synthesis of SH relative to CG.

Addition of SB extract to the ration did not affect the cecal fermentation parameters probably due to its inefficiency in improving fermentation efficiency, fermentation kinetics, and GP [17]. Parra-García et al [17] observed unaffected fermentation kinetics with the addition of SB extract to rations containing different levels of prickly pear cactus as a replacement of $C G$.

\section{Conclusions}

Results of GP and fermentation kinetics showed that SH has a potential fermentation efficiency and fermentation 
kinetics superior to that of CG and that $\mathrm{SH}$ can replace $\mathrm{CG}$ in the diet of horses. The level of $75 \mathrm{~g} \mathrm{SHs} / \mathrm{kg}$ DM is the best level of inclusion (replacement of CG at 30\%). Further in vivo trials with different levels of SH replacing CG in the presence or absence of SB extract inclusion should be conducted to validate current findings.

\section{References}

[1] Khattab HM, Gado HM, Salem AZM, Camacho LM, El-Sayed MM, Kholif AM, El-Shewy AA, Kholif AE. Chemical composition and in vitro digestibility of Pleurotus ostreatus spent rice straw. Anim Nutr Feed Technol 2013;13:507-16.

[2] Abdel-Aziz NA, Salem AZ, El-Adawy MM, Camacho LM, Kholif AE, Elghandour MMY, Borhami BE. Biological treatments as a mean to improve feed utilization in agriculture animals-an overview. J Integr Agric 2015;14:534-43.

[3] Togtokhbayar N, Cerrillo MA, Rodríguez GB, Elghandour MM, Salem AZM, Urankhaich C, Jigjidpurev S, Odongo NE, Kholif AE. Effect of exogenous xylanase on rumen in vitro gas production and degradability of wheat straw. Anim Sci J 2015;86:765-71.

[4] Elghandour MMY, Kholif AE, Hernández J, Mariezcurrena MD, López S, Camacho LM, Márquez O, Salem AZM. Influence of the addition of exogenous xylanase with or without pre-incubation on the in vitro ruminal fermentation of three fibrous feeds. Czech J Anim Sci 2016;61:262-72.

[5] Elghandour MMY, Kholif AE, Salem AZM, Olafadehan OA, Kholif AM. Sustainable anaerobic rumen methane and carbon dioxide productions from prickly pear cactus flour by organic acid salts addition. J Clean Prod 2016;139:1362-9.

[6] Kholif AE, Elghandour MMY, Rodríguez GB, Olafadehan OA, Salem AZM. Anaerobic ensiling of raw agricultural waste with a fibrolytic enzyme cocktail as a cleaner and sustainable biological product. J Clean Prod 2017;142:2649-55.

[7] Costa SBM, Ferreira MA, Pessoa RAS, Batista AMV, Ramos AO, da Conceição MG, Gomes LHS. Tifton hay, soybean hulls, and whole cottonseed as fiber source in spineless cactus diets for sheep. Trop Anim Health Prod 2012;44:1993-2000.

[8] Elghandour MMY, Kholif AE, Salem AZM, de Oca RM, Barbabosa A, Mariezcurrena M, Olafadehan OA. Addressing sustainable ruminal methane and carbon dioxide emissions of soybean hulls by organic acid salts. J Clean Prod 2016;135:194-200.

[9] Velázquez AE, Kholif AE, Elghandour MM, Salem AZM, de Oca Jiménez RM, Pliego AB, Odongo N, Bórquez JL, Cipriano M, Olivares J. Effect of partial replacement of steam rolled corn with soybean hulls or prickly pear cactus in the horse's diet in the presence of live Saccharomyces cerevisiae on in vitro fecal gas production. J Equine Vet Sci 2016:42:94-101.

[10] Morsy TA, Kholif AE, Kholif SM, Kholif AM, Sun X, Salem AZM. Effects of two enzyme feed additives on digestion and milk production in lactating Egyptian buffaloes. Ann Anim Sci 2016;16:209-22.

[11] Rojo R, Kholif AE, Salem AZM, Elghandour MMY, Odongo NE, de Oca RM, Rivero N, Alonso MU. Influence of cellulase addition to dairy goat diets on digestion and fermentation, milk production and fatty acid content. J Agric Sci 2015;153:1514-23.

[12] Salem AZM, Elghandour MMY, Kholif AE, Odongo NE, Jiménez FJ, Montes de Oca R, Domínguez IA, Dibarrat JA. The effect of feeding horses a high fiber diet with or without exogenous fibrolytic enzymes supplementation on nutrient digestion, blood chemistry, fecal coliform count, and in vitro fecal fermentation. J Equine Vet Sci 2015:35:735-43.

[13] Rodriguez MP, Mariezcurrena MD, Mariezcurrena MA, Lagunas BC, Elghandour MMY, Kholif AM, Kholif AE, Almaráz EM, Salem AZM. Influence of live cells or cells extract of Saccharomyces cerevisiae on in vitro gas production of a total mixed ration. Ital J Anim Sci 2015; 14:590-5.

[14] Salem AZM, Elghandour MMY, Kholif AE, Barbabosa A, Camacho LM, Odongo NE. Influence of feeding horses a high fiber diet with or without live yeast cultures supplementation on feed intake, nutrient digestion, blood chemistry, fecal coliform count, and in vitro fecal fermentation. J Equine Vet Sci 2016;39:12-9.

[15] Rivero N, Salem AZM, Ayala-Martinez M, Elghandour MMY, Kholif AE, Barbabosa A, Camacho LM, Rojas S, Olivares J, Cipriano M. Influence of Salix babylonica extract, exogenous enzyme of xylanase and their combination on blood hematological and biochemical profile in sheep and goats. Indian J Anim Sci 2016;86:1140-4.
[16] Valdes KI, Salem AZM, López S, Alonso MU, Rivero N, Elghandour MMY, Domínguez IA, Ronquillo MG, Kholif AE. Influence of exogenous enzymes in presence of Salix babylonica extract on digestibility, microbial protein synthesis and performance of lambs fed maize silage. J Agric Sci 2015;153:732-42.

[17] Parra-Garcia A, Salem AZM, Elghandour MMY, Camacho LM, Odongo N. Potential impact of prickly pear cactus flour and Salix babylonica extract on cecal fermentation and methane production in horses. Agroforest Syst 2017. http://dx.doi.org/10.1007/s10457016-0051-8.

[18] Cedillo J, Vázquez-Armijo JF, González-Reyna A, Salem AZM, Kholif AE, Hernández-Meléndez J, Martínez-González JC, de Oca Jiménez RM, Rivero N, López D. Effects of different doses of Salix babylonica extract on growth performance and diet in vitro gas production in Pelibuey growing lambs. Ital J Anim Sci 2014;13:609-13.

[19] Salem AZM, Ryena AC, Elghandour MMY, Camacho LM, Kholif AE, Salazar MC, Domínguez IA, Jiménez RM, Almaraz EM, Martínez AGL, Mariezcurrena MA. Influence of Salix babylonica extract in combination or not with increasing levels of minerals mixture on in vitro rumen gas production kinetics of a total mixed ration. Ital J Anim Sci 2014;13:873-9.

[20] Salem AZM, Kholif AE, Elghandour MMY, Hernández J, Limas A, Cipriano M, Camacho L, Rojas S, Olivares J. Influence of Salix babylonica extract addition on in vitro rumen gas production and degradability of ryegrass silage harvested in different cutting days. Indian J Anim Sci 2016;86:1030-5.

[21] Salem AZM, Kholif AE, Elghandour MMY, Buendía G, Mariezcurrena MD, Hernandez SR, Camacho LM. Influence of oral administration of Salix babylonica extract on milk production and composition in dairy cows. Ital J Anim Sci 2014;13:10-4.

[22] Cedillo J, Kholif AE, Salem AZM, Elghandour MMY, Vázquez JF, Alonso MU, Barbabosa A, Chagoyán JCV, Reyna AG. Oral administration of Sauce llorón extract to growing lambs to control gastrointestinal nematodes and Moniezia spp. Asian Pac J Trop Med 2015; 8:520-5.

[23] Salem AZM, Elghandour MMY, Kholif AE, López S, Pliego AB, Cipriano-Salazar M, Chagoyán JCV, de Oca Jiménez RM, Alonso MU. Tree leaves of Salix babylonica extract as a natural anthelmintic for small-ruminant farms in a semiarid region in Mexico. Agroforest Syst 2017. http://dx.doi.org/10.1007/s10457-016-9909-z.

[24] Goering MK, Van Soest PJ. Forage fibre analysis (apparatus, reagents, procedures and some applications). Washington, DC, USA: Agricultural Research Service, USDA; 1970.

[25] Theodorou MK, Williams BA, Dhanoa MS, McAllan AB, France J. A simple gas production method using a pressure transducer to determine the fermentation kinetics of ruminant feeds. Anim Feed Sci Technol 1994;48:185-97.

[26] Association of Official Analytical Chemists (AOAC). Official methods of analysis. 16th ed. Arlington, VA, USA: AOAC; 1997.

[27] SAS. User's guide: statistics, version 9.0. Cary, NC: SAS Institute; 2002.

[28] France J, Dijkstra J, Dhanoa MS, López S, Bannink A. Estimating the extent of degradation of ruminant feeds from a description of their gas production profiles observed in vitro: derivation of models and other mathematical considerations. Br J Nutr 2000;83:143-50.

[29] Menke KH, Raab L, Salewski A, Steingass H, Fritz D, Schneider W. The estimation of the digestibility and metabolizable energy content of ruminant feeding stuffs from the gas production when they are incubated with rumen liquor in vitro. J Agric Sci 1979;93:21722.

[30] Blümmel M, Steingss H, Becker K. The relationship between in vitro gas production, in vitro microbial biomass yield and ${ }^{15} \mathrm{~N}$ incorporation and its implications for the prediction of voluntary feed intake of roughages. Br J Nutr 1997; 77:911-21.

[31] Getachew G, Makkar HPS, Becker K. Tropical browses: contents of phenolic compounds, in vitro gas production and stoichiometric relationship between short chain fatty acid and in vitro gas production. J Agric Sci 2002;139:341-52.

[32] Vallejo L, Salem AZM, Kholif AE, Elghangour M, Fajardo R, Rivero N, Bastida A, Mariezcurrena M. Influence of cellulase or xylanase on the in vitro rumen gas production and fermentation of corn stover. Indian J Anim Sci 2016;86:70-4.

[33] Elghandour MMY, Kholif AE, Marquez-Molina O, Vazquez-Armijo JF, Puniya AK, Salem AZM. Influence of individual or mixed cellulase and xylanase mixture on in vitro rumen gas production kinetics of total mixed rations with different maize silage and concentrate ratios. Turk J Vet Anim Sci 2015;39:435-42.

[34] Elghandour MMY, Kholif AE, Bastida AZ, Martínez DLP, Salem AZM. In vitro gas production of five rations of different maize silage and 
concentrate ratios influenced by increasing levels of chemically characterized extract of Salix babylonica. Turk J Vet Anim Sci 2015; 39:186-94.

[35] Blümmel M, Ørskov ER. Comparison of in vitro gas production and nylon bag degradability of roughages in predicting feed intake in cattle. Anim Feed Sci Technol 1993;40:109-19.

[36] Khazaal K, Dentinho MT, Ribeiro JM, Ørskov ER. Prediction of apparent digestibility and voluntary feed intake of hays fed to sheep: comparison between using fibre component, in vitro digestibility or characteristics of gas production or nylon bag degradation. Anim Sci 1995;61:521-38.

[37] Okunade SA, Olafadehan OA, Isah OA. Fodder potential and acceptability of selected tree leaves by goats. Anim Nutr Feed Technol 2014;14:489-98.

[38] Hart KJ, Yanez-Ruiz DR, Duval SM, McEwan NR, Newbold CJ. Plant extracts to manipulate rumen fermentation. Anim Feed Sci Technol 2008;147:8-35.

[39] Elghandour MMY, Vázquez JC, Salem AZM, Kholif AE, Cipriano MM, Camacho LM, Márquez O. In vitro gas and methane production of two mixed rations influenced by three different cultures of Saccharomyces cerevisiae. J Appl Anim Res 2017;45:389-95.

[40] Intergovernmental panel on climate change. Climate change, 2007. Synthesis report. Contribution of working group I, II, and III to the fourth assessment report of the Intergovernmental Panel on Climate Change. Geneva, Switzerland: IPCC; 2008.

[41] Johnson KA, Johnson DE. Methane emissions from cattle. J Anim Sci 1995:73:2483-92.

[42] Ørskov ER, Ryle R. Energy nutrition in ruminants. New York: Elsevier SciencePublishers; 1990.

[43] Dhanoa MS, Lopez S, Dijkstra J. Estimating the extent of degradation of ruminant feeds from a description of their gas production profiles observed in vitro: comparison of models. Br J Nutr 2000;83: $131-42$.

[44] Kholif AE, Gouda GA, Morsy TA, Salem AZM, Lopez S, Kholif AM. Moringa oleifera leaf meal as a protein source in lactating goat's diets: feed intake, digestibility, ruminal fermentation, milk yield and composition, and its fatty acids profile. Small Rumin Res 2015;129: 129-37.

[45] Kholif AE, Morsy TA, Abd El Tawab AM, Anele UY, Galyean ML. Effect of supplementing diets of Anglo-Nubian goats with soybean and flaxseed oils on lactational performance. J Agric Food Chem 2016; 64:6163-70.

[46] Forsberg C, Forano E, Chesson A. Microbial adherence to the plant cell wall and enzymatic hydrolysis. In: Cronje PB, editor. Ruminant physiology: digestion, metabolism, growth and reproduction. Wallingford, UK: CABI Publishing; 2000. p. 79-97. 